\title{
Prevalence, mechanical transmission and impact of environmental conditions on cucumber mosaic disease in Sindh
}

\author{
Muhammad Sabir Bhutto ${ }^{1}$, Jamal-U-Ddin Hajano ${ }^{1 *}$, Abdul Ghani \\ Kandhro ${ }^{1}$, Zubair Ahmed Nizamani ${ }^{1}$, Khalid Hussain Dhiloo ${ }^{2}$, Lemon \\ Kumar $^{3}$, Khadim Hussain Wagan ${ }^{1}$ and Aftab Raza Jarwar ${ }^{2}$ \\ 1. Department of Plant Pathology, Faculty of Crop Protection, Sindh Agriculture University, Tandojam 70060- \\ Pakistan \\ 2. Department of Entomology, Faculty of Crop Protection, Sindh Agriculture University, Tandojam 70060- \\ Pakistan \\ 3. Plant Pathology Section, Agriculture Research Institute (ARI), Tandojam70060-Pakistan \\ *Corresponding author's email: jhajano@sau.edu.pk; hajanojamal@gmail.com \\ Citation \\ Muhammad Sabir Bhutto, Jamal-U-Ddin Hajano, Abdul Ghani Kandhro, Zubair Ahmed Nizamani, Khalid \\ Hussain Dhiloo, Lemon Kumar, Khadim Hussain Wagan and Aftab Raza Jarwar. Prevalence, mechanical \\ transmission and impact of environmental conditions on cucumber mosaic disease in Sindh. Pure and Applied \\ Biology. Vol. 8, Issue 2, pp1051-1061. http://dx.doi.org/10.19045/bspab.2019.80046
}

\begin{tabular}{llll}
\hline \hline Received: 05/01/2019 & Revised: 25/03/2019 & Accepted: 29/03/2019 & Online First: 05/04/2019 \\
\hline \hline
\end{tabular}

\section{Abstract}

Cucumber mosaic virus (Genus: Cucumovirus, Family: Bromoviridae) is major pathogen of cucumber (Cucumis sativus L.) in Pakistan and may cause up to $100 \%$ losses. Therefore, this survey based study was planned to determine the disease intensity in fields, mechanical transmission for confirmation of virus and analysis of influence of environmental conditions on the disease development. The disease was monitored on 30 plants at each site in district Hyderabad, Tando Allahyar, Thatta and Shaheed Benazirabad. There were seven sites at each district for observations. Metrological data collected from Regional Agro Metrological Centre, ARI Tandojam Sindh was correlated with the disease intensity. The disease incidence was ranging, 40- 77, 37- 70, 63- 100 and 30- 90\%, at district Hyderabad, Tando Allahyar, Thatta and Shaheed Benazirabad, respectively. District wise, there was highly significant variation among incidence of cucumber mosaic disease $(\mathrm{Df}=3, \mathrm{~F}=20.59, P=0.0000)$. Maximum disease incidence was recorded at Thatta $(81.0 \%)$. However, overall severity of cucumber mosaic in all the surveyed districts was 2 -score. On mechanical inoculation, after 15 days necrotic lesions were only found on the leaves of Chenopodium amaranticolor inoculated with sap of symptomatic leaves. Maximum, minimum temperature $\left({ }^{\circ} \mathrm{C}\right)$ and evaporation showed significant relation $\left(r^{2}=0.883, P=0.0053, r^{2}=0.664, P=\right.$ 0.0482 and $r^{2}=0.827, P=0.0119$, respectively) only with the disease incidence but not with severity. Cloudiness was highly significantly related with disease severity $\left(r^{2}=0.975, P=0.0002\right)$ but there was non-significant relationship with disease incidence $\left(r^{2}=0.600, P=0.0705\right)$.

Keywords: Cucumber; Disease intensity; Environmental conditions; Mechanical transmission; Mosaic virus

\section{Introduction}

Cucumber (Cucumis sativus L.) is a famous vegetable under family, Curcubitaceae. Cucumber is being grown thought out the world including Pakistan [1, 2]. In Pakistan, during 2016 cropping season, the crop is cultivated in an area of about 3,482 ha with a total production of 56,204 tons [3]. Cucumber production is adversely affected by biotic and abiotic factors. Among biotic 
factors, cucumber mosaic virus (CMV) (Genus: Cucumovirus, Family: Bromoviridae) is one of the devastating plant virus with wide host range, spread and causing huge production losses. Such features are considered to be key factors for the virus epidemics in host plants. CMV may cause up to $100 \%$ losses in susceptible host plant under favourable environmental conditions [4]. The CMV's extensive host rang contains several species of crops, which play a role as a source of CMV, also for the spreading of virus the various crops. The reports proved that CMV infects about 1287 species of plants, which includes fruits, cucurbits, vegetables, ornamental, medicinal and weeds. The most important affected vegetables by CMV are included cucurbits, tomatoes and chillies $[5,6]$.

Plants can be attacked by the virus throughout cropping season but six to eightleaf stage is consider ideal for the attack. The virus may colonize vascular tissues, disturb chlorophyll and internode growth of plants if attack initiated in seedlings. New leaves are slightly mottled, wrinkled and distorted with a slight downward curling of the edges. On the older leaves greenishyellow lesions along with leaf veins are induced due to infection of the virus. Leaves are curled downward with wrinkled leaf lemina. Eventually, a yellow-green mottling develops. Occasionally, only the leaf tip turns yellowish without a sharply defined mottle. After infection, plant growth is stunted with shortened internodes. In lush growing crops, infected vines may wither before showing signs of distortion and may die within seven days. Few fruits are set once infection occurs and fruit that does set has a yellow-green mottle on the stem, gradually extending over the entire fruit surface, interspersed with dark green areas that are usually raised and wartlike. Occasionally, fruit becomes smooth, green-white and blunt at the end. Soggy pickles and bitter taste are the symptoms in cucumber infected by CMV [7].

There are about 75 aphid vector species responsible for transmission of $\mathrm{CMV}$ in non-persistent manner. Additionally, there is highly specification among isolates and aphid species to transmit the virus $[8,9]$. The virus is also sap/mechanical transmissible to the host or indicator plants $[4,10,11]$. The plants which are parasitic such as dodder (Cuscuta spp.) are also responsible for CMV transmission and in some cases; it is transmitted through seeds [12].

The disease could be assessed using descriptive plant material or given pictorial keys and using modern techniques based on monitoring of infectious organisms [13, 14]. The visual test of a disease in terms of severity, incidence is easy, cheap and effectively correlated with losses of yield in the crop [13, 15]. Furthermore, the infection of viral disease in plant is recognized either by electron microscopy, ELISA, monoclonal antibody techniques, Northern, Southern Blotting, PCR/RTPCR, microarray technologies, biosensors, etc., which are widely used for their sensitivity, rapidity and accuracy throughout the world [16, 17].

Although using such methodology, prevalence of CMV in chilli/pepper is investigated throughout Pakistan [18] but its spread in cucumber crop is not assessed yet. Such assessment in field conditions is playing critical role for any quantitative epidemiological study and is essential base line for conducting field based experiments in order to provide proficient and reliable management practice for managing the disease even at high disease rick point. Furthermore, environmental factors such relative humidity, rainfall, temperature are shown to interact with development of CMV and its vector population [19]. Therefore, this survey based study was planned to determine the disease intensity in fields, mechanical transmission for confirmation of virus and analysis of influence of environmental conditions on the disease development.

\section{Materials and methods}

Hyderabad, Tando Allahyar, Thatta and Shaheed Benazirabad district were selected 
for visual assessment of the disease under field conditions at commercial farmer fields. Fields were surveyed with the willingness of farmers to participate in the survey and easily feasibility to conduct observation for covering main cucumber growing areas. Fields were managed by growers as recommended production practices. Ten cucumber plants with three replications $(N=30)$ at each location were observed for the symptoms of the disease. The disease incidence percentage was calculated by dividing number of cucumber plants showing mosaic symptoms with total number of plants examined for the disease. Severity of the disease was measured by using 1-5 rating scale [4]. Mechanical transmission of CMV was done on Chenopodium amaranticolor by rubbing the extract on wounded leaves. CMV infected leave tissues $(5 \mathrm{~g})$ were collected and crushed in sterilized pestle and mortar in $10 \mathrm{ml}$ phosphate buffer (2.4 gm of $\mathrm{KH}_{2} \mathrm{PO}_{4}$ and $5.4 \mathrm{gm}$ of $\mathrm{KH}_{2} \mathrm{PO}_{4}$ in one litre water). Carborundum powder was used to provide tiny wounds for entry of the virus particles in the leaf tissues, then leaves were inoculated with prepared sap. After inoculation leaves tap water was applied to remove excess sap on wounds and plants were shifted in dark for symptoms development as described by [4]. Plants were kept under observation until the symptom inducement. There was a control treatment which was treated with Carborundum powder but sap was not applied. Metrological data was collected from Regional Agro Metrological Centre, Agriculture Research Institute, Tandojam Sindh. Analysis of variance was performed to determine least significant difference among the disease parameters and aphid population $\alpha=0.005$. Test was performed using STATISTIX v. 8.1 software (Analytical Software). Correlation of the disease parameters with environmental factors was performed using PRISM v. 5.01 (GraphPad Software).

\section{Results and discussion \\ The incidence and severity of cucumber mosaic disease}

In district Hyderabad, maximum the disease incidence 77.0, 73.0 and 63.0\% was recorded at locations of Amar Town-1, Amar Town-2 and New Hyderabad City, respectively followed by Rahuki-2 and Channel (50.0\%) (Figure 1). Rahuki-1 locality showed significantly lower (40.0\%) incidence of cucumber mosaic disease followed by locality of Detha Stop $(47.0 \%)$ (Figure 1). Ibrahim Shah-2 location of district Tando Allahyar showed significantly maximum $70.0 \%$ incidence of cucumber mosaic disease, followed by Khawaja Stop (67.0\%), Mirpur Bypass (63.0\%), Tando Allahyar and Bukera Road (57.0\%). Minimum incidence of cucumber mosaic disease was recorded $37.0 \%$ at location of Keeria Shakh of district Tando Allahyar (Figure 2). There was significant variation in the disease incidence $(\%)$ at surveyed locations of district Thatta $(\mathrm{Df}=6$, $\mathrm{F}=4.19, \mathrm{P}=0.0167)$. Cucumber crop grown nearby Bharosal Colony of Thatta was $100 \%$ infected with the virus (Figure 3). The disease incidence at Var was $90.0 \%$, which was non-significantly differing with incidence recorded at Karimabad $(83.0 \%)$. Minimum $63.0 \%$ incidence of cucumber mosaic was recorded at DC Gull Hassan Nahiyoo followed by locality of Ghulamullah (80.0\%), Thatta $(76.0 \%)$ and Mirpur Sakro (73.0\%) (Figure 3). The cucumber mosaic disease incidence showed highly significant variation at surveyed locations of Shaheed Benazirabad ( $\mathrm{Df}=6$, $\mathrm{F}=31.27, \mathrm{P}=0.0000$ ). The maximum disease incidence was recorded at Kazi Ahmed (90.0\%), followed by Bhalu Ja Kuba-1 (70.0\%) (Figure 4). Sahpur Jahania and Dolatpur Safan showed $50.0 \%$ incidence of the disease. Minimum incidence $30.0 \%$ was recorded at Bhalu Ja Kuba-2 followed by Deh Phulail and Chanesar Stop (37.0\%) (Figure 4).

District wise, there was highly significant variation among incidence of cucumber mosaic disease $(\mathrm{Df}=3, \mathrm{~F}=20.59, \mathrm{P}=$ 
0.0000). Maximum disease incidence was recorded at Thatta $(81.0 \%)$ (Figure 5). However, incidence at district Shaheed Benazirabad (52.0\%) was lower and nonsignificantly differs with Tando Allahyar $(56.0 \%)$ and Hyderabad (57.0\%) (Figure 5). In Hyderabad district the maximum severity 3-score was recorded at Amar Town-1 and minimum 1-severity score was determined at field of Rahuki-1, remaining showed 2-severity score (Figure 6). Mirpur Bypass locality of Tando Allahyar district showed maximum 3 severity score, whereas other all fields of the district showed 2 severity score (Figure 7). In district Thatta the maximum cucumber mosaic severity 3-score was recorded at Bharosal Colony and Karimabad, whereas at other remaining fields it was 2 score (Figure 8). Kazi Ahmed locality of district Shaheed Benazirabad showed maximum 3 severity score followed by Dolatpur Safan, Bhalu Ja Kuba-1 and Chanesar Stop with 2 severity score (Figure 9). The locality of Sahpur Jahania, Deh Phulail, and Bhalu Ja Kuba-2 showed minimum 1 severity score (Figure 9). Overall severity of cucumber mosaic in all the surveyed districts was 2score (Figure 10).

It is concluded from our study that the cucumber mosaic disease is prevailing in all the sites surveyed in four districts of Sindh. The incidence percentage was varying site to site and some were showing nonsignificant variations in the incidence values. District wise, there was highly significant variation among incidence of cucumber mosaic disease $(\mathrm{Df}=3, \mathrm{~F}=20.59$, $\mathrm{P}=0.0000$ ). Maximum disease incidence was recorded at Thatta. However, incidence at district Shaheed Benazirabad was lower, but non-significantly differing with Tando Allahyar and Hyderabad. Similarly variation in the disease severity at site to site was found in survey. Overall severity of cucumber mosaic in all the surveyed districts was 2-score. Similar, studies are conducted at different regions of the world [20-22]. Iqbal [18] monitored and recorded CMV incidence in chili pepper in all over
Pakistan during the year 2006-07. During survey 706 total number of samples were collected from various provinces (Baluchistan 207, Sindh 191, KPK 51 and Panjab 257) and has been tested through DAC-ELISA. The results of ELISA showed that CMV occurs all over the Pakistan with $44.7 \%$ of relative incidence. Sindh province found most effected with (51.8\%) maximum incidence of CMV and Baluchistan province $(17.47 \%)$ which is followed by Punjab and KPK with $(8.5 \%)$ and $(7.8 \%)$ incidence respectively. In Sindh and Baluchistan provinces there was not a single district free from CMV infection. Aphid has also been identified as positional vector of the virus [23-25].

\section{Pathogenicity test for confirmation of viral infection}

Pathogenicity test was performed on Chenopodium amarenticolor indicator plants by mechanical inoculation method. After about one month of sowing plants were rubbed with sap of symptomatic plants collected from field. In control treatment the plants were rubbed with carborandum powder but sap was not applied (Figure 11). After 15 days of inoculation necrotic lesions were found on the leaves of inoculated with sap but in control plants leaves were free of necrotic lesions (Figure 12). Such results are in accordance with $[10,26]$ who performed mechanical transmission of CMV on indicator plant (C. amarenticolor) which was grown in an insect proof net house using five inches earthen pot. The soil used in the pot is amended with manure and fertilizer as per recommendation. Three different buffers namely $0.01 \mathrm{M}$ potassium phosphate buffer ( $\mathrm{pH}$ 7.1), sodium phosphate buffer ( $\mathrm{pH} 7.1)$ and sodium potassium phosphate buffer $(\mathrm{pH}$ 7.1) are used to extract sap of infected chilli leaves in the inoculation test. In each case, $5 \mathrm{~g}$ fresh leaves collected from infected chilli plants is macerated using $50 \mathrm{ml}$ aforesaid buffers for sap extraction. On inoculation, necrotic lesions were observed on inoculated plants. 
Correlation between cucumber mosaic viral disease and environmental factors

Impact of environmental conditions like minimum and maximum temperature $\left({ }^{\circ} \mathrm{C}\right)$, relative humidity $(\%)$, cloudiness and evaporation on cucumber mosaic disease was tested. Minimum Temperature $\left({ }^{\circ} \mathrm{C}\right)$ showed significant correlation with the disease incidence $\left(r^{2}=0.664, P=0.0482\right)$ but it was non-significantly correlated with severity of cucumber mosaic disease (Table 1). Similarly, maximum temperature $\left({ }^{\circ} \mathrm{C}\right)$ showed significant correlation with the disease incidence $\left(r^{2}=0.883, P=0.0053\right)$ but non-significant with the disease severity $\left(r^{2}=0.148, P=0.4522\right)$ (Table 1$)$. Cloudiness was highly significantly correlated with disease severity $\left(r^{2}=0.975\right.$, $P=0.0002)$ but there was no relationship with disease incidence $\left(r^{2}=0.600, P=\right.$ 0.0705 ) (Table 1). The disease incidence (\%) was dependent with evaporation $\left(r^{2}=\right.$ $0.827, P=0.0119)$ but not with severity $\left(r^{2}=\right.$ $0.599, P=0.0708$ ) (Table 1).

Our results showed that minimum and maximum temperature $\left({ }^{\circ} \mathrm{C}\right)$ were significantly correlated with the disease incidence but it was non-significantly correlated with severity of cucumber mosaic disease. Cloudiness was highly significantly correlated with disease severity but there was no relationship with disease incidence. The disease incidence (\%) was dependent with evaporation but not with severity. Previously, Khan et al. [19] in a field study showed impact of environmental conditions on development of CMV that relative humidity and rainfall are important factor for the disease development while temperature is negatively correlated with disease development. Similarly, Imran et al. [27] showed increase in ToMV severity with temperature but decreased with increase in relative humidity. Such studies are also conducted by various authors for many different viral diseases, like Zeshan et al. [28] showed direct relationship of TLCV with temperature but it was not increasing with increase in relative humidity, while rainfall and wind speed were not related with disease development. Likewise, Haider et al. [29] assessed relationship of epidemiological factors among whitefly population and tomato leaf curl virus disease (TLCVD) incidence was studied on six tomato varieties. Epidemiological factors have significant role for the development of whitefly and TLCVD incidence during 2016. Temperature (maximum and minimum) had positively significant relationship for whitefly population and disease incidence. With increase in maximum temperature whitefly population showed $77-99 \%$ variability while with minimum temperature it was 66$99 \%$ variability. TLCVD incidence showed $84-96 \%$ variability with minimum temperature while $86-96 \%$ with maximum temperature. Relative humidity had negatively significant relationship with whitefly population and disease incidence. With increase in relative humidity whitefly population and TLCVD incidence decreased. Relative humidity showed 75$96 \%$ and $83-93 \%$ variability in case of whitefly population and disease incidence respectively. Wind speed and rainfall have very poor relationship with vector population and disease incidence. 


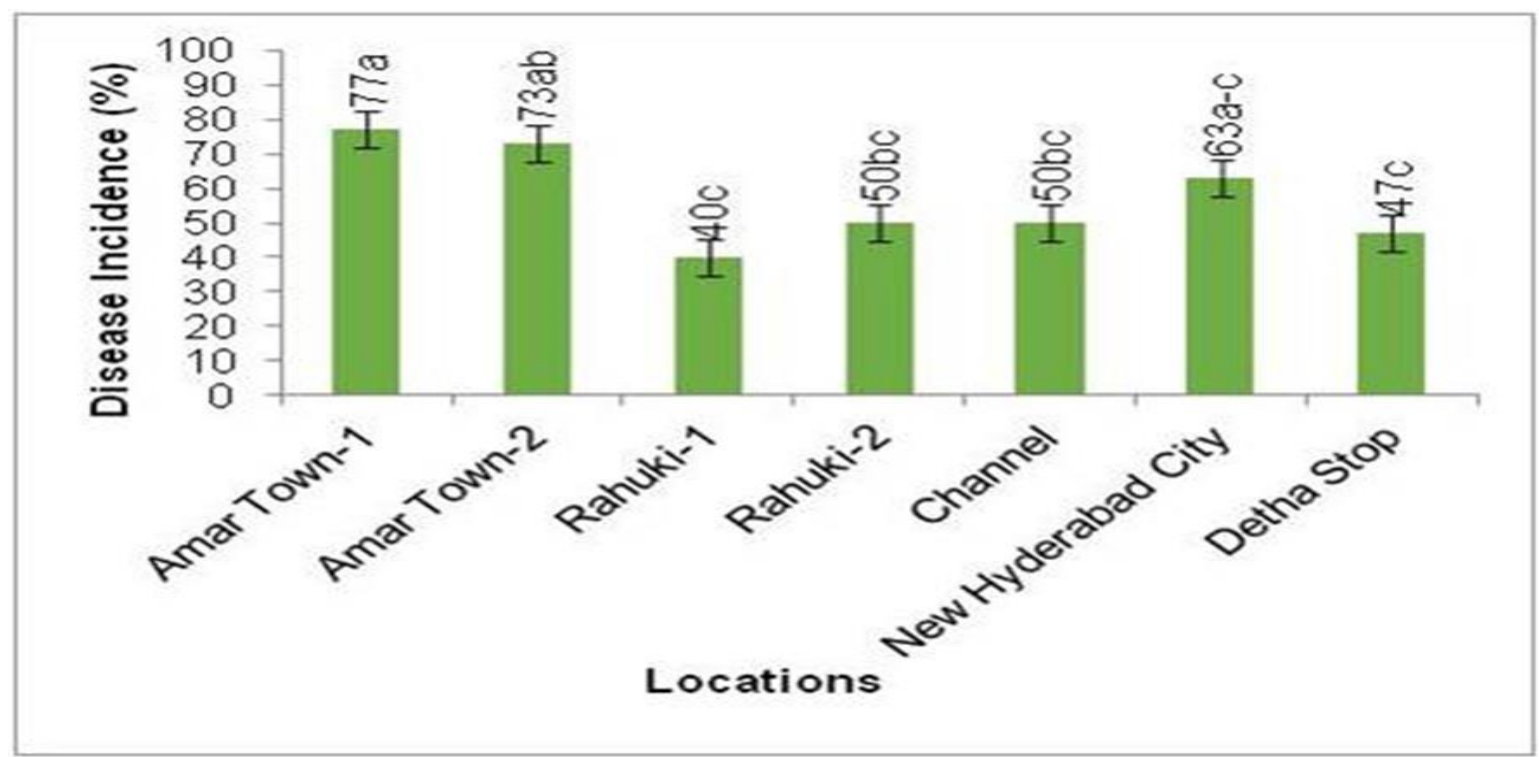

Figure 1. Cucumber mosaic disease incidence (\%) at different locations of district Hyderabad

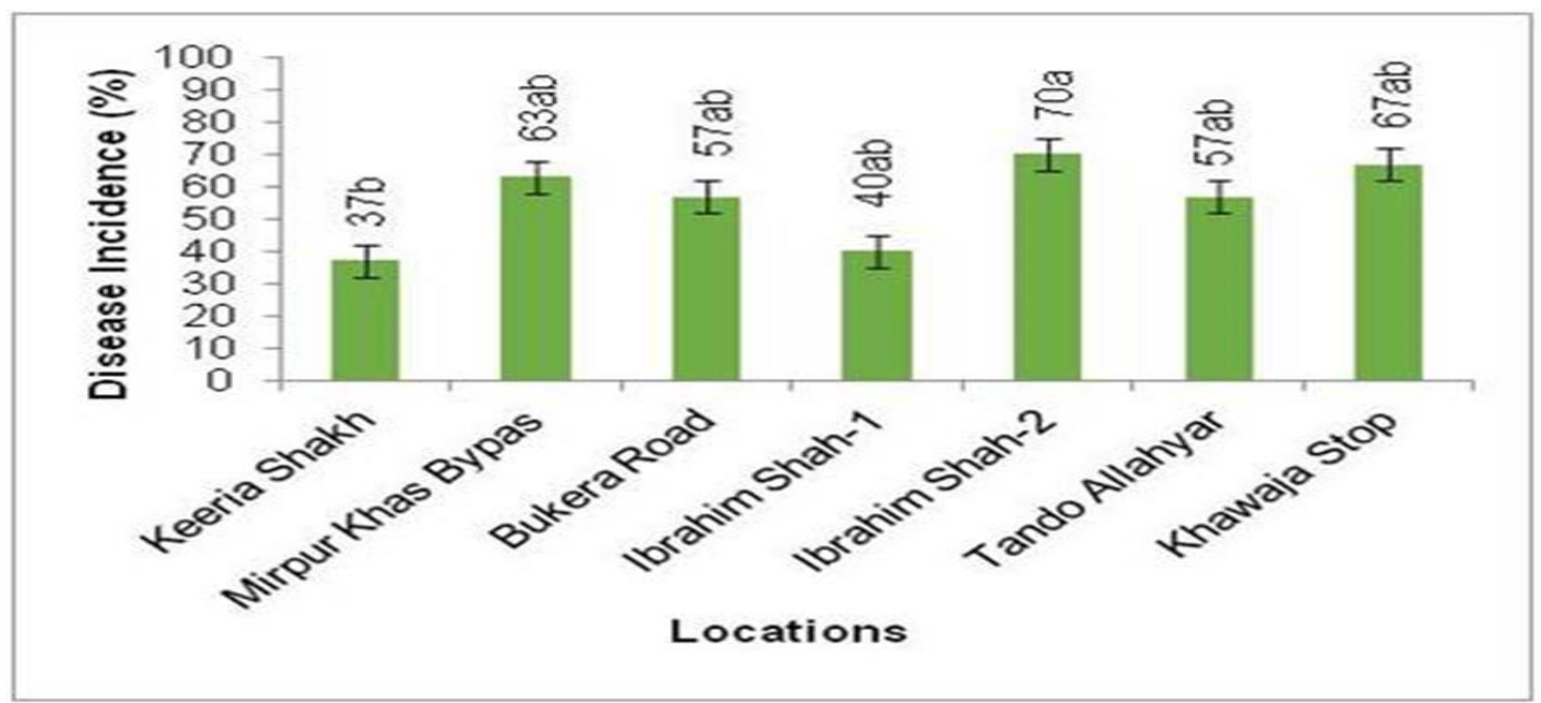

Figure 2. Cucumber mosaic disease incidence $(\%)$ at different locations of district Tando Allahyar

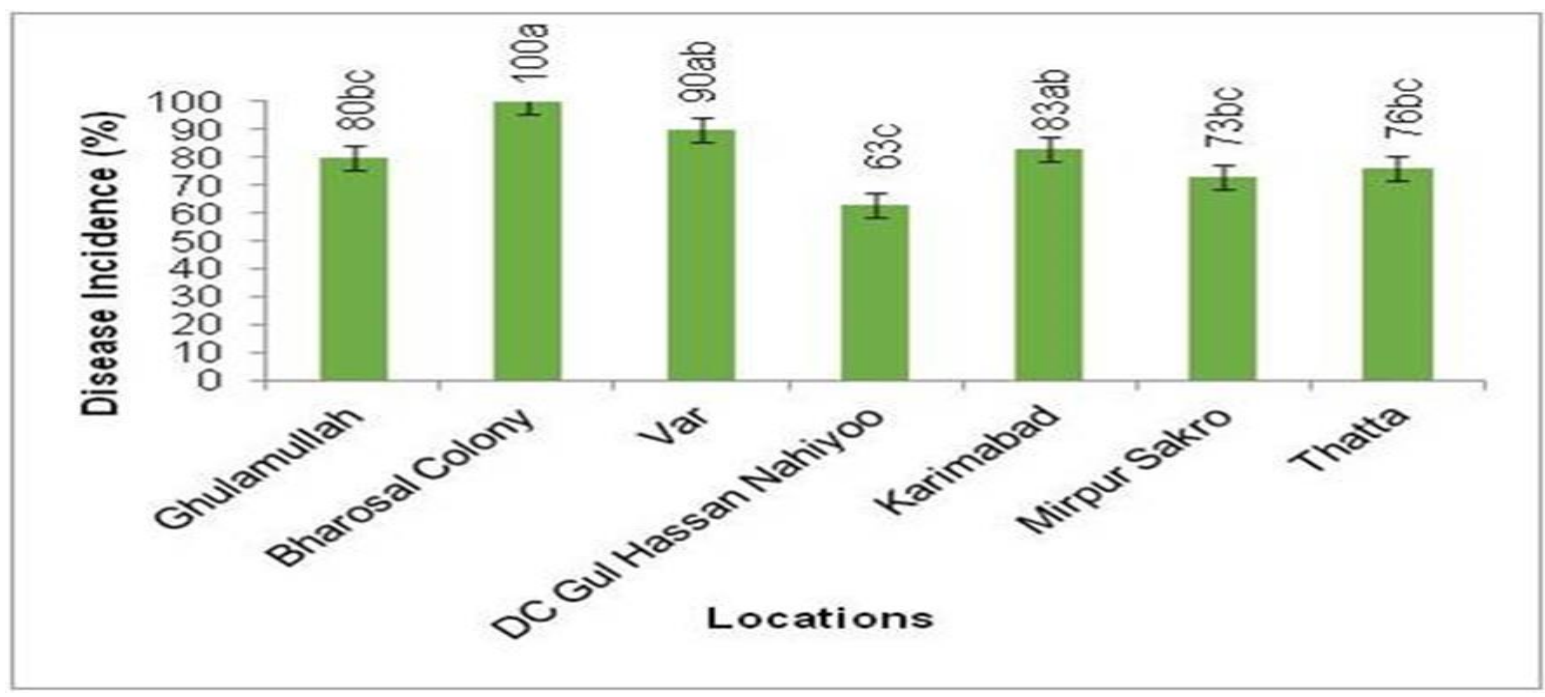

Figure 3. Cucumber mosaic disease incidence (\%) at different locations of district Thatta 


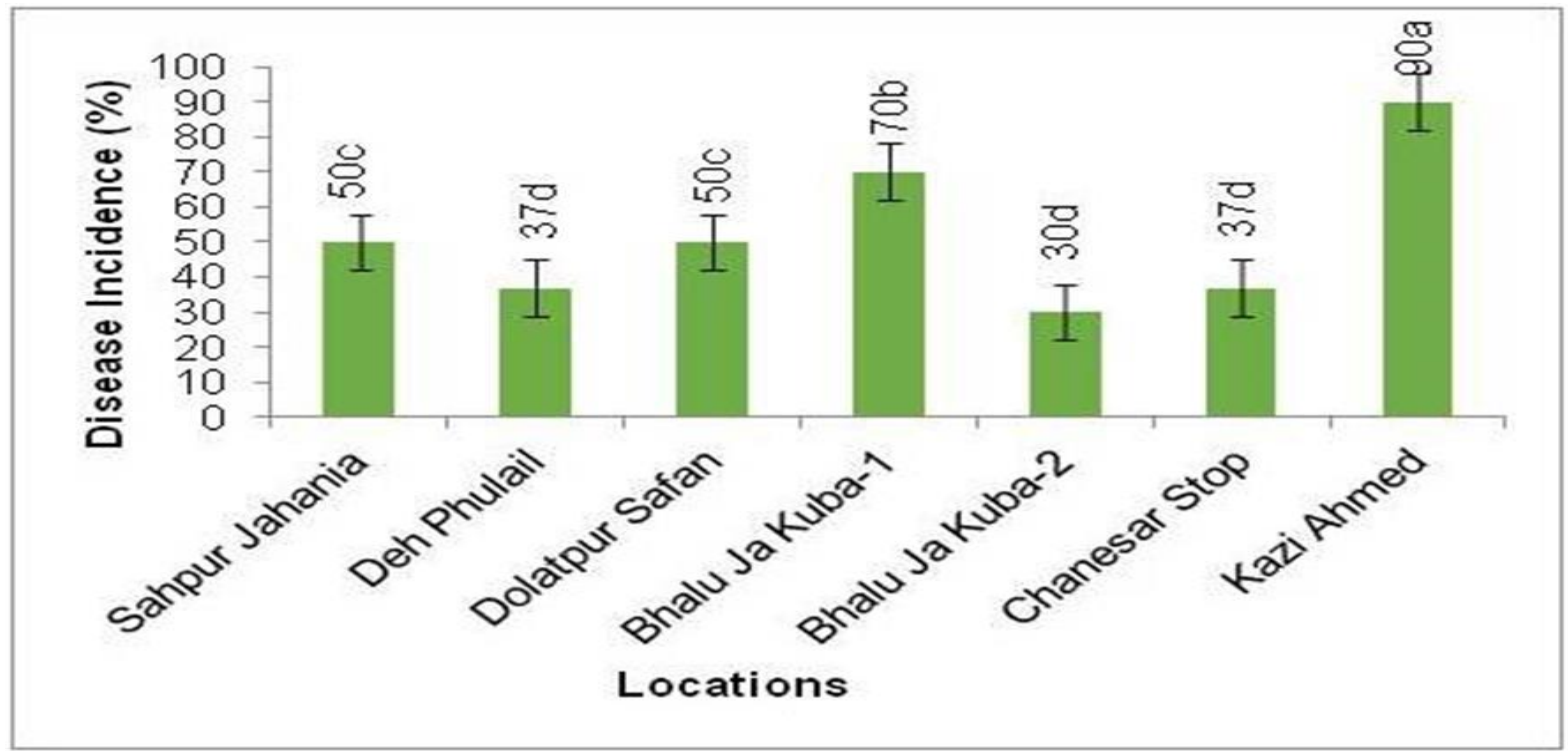

Figure 4. Cucumber mosaic disease incidence (\%) at different locations of district Shaheed Benazirabad

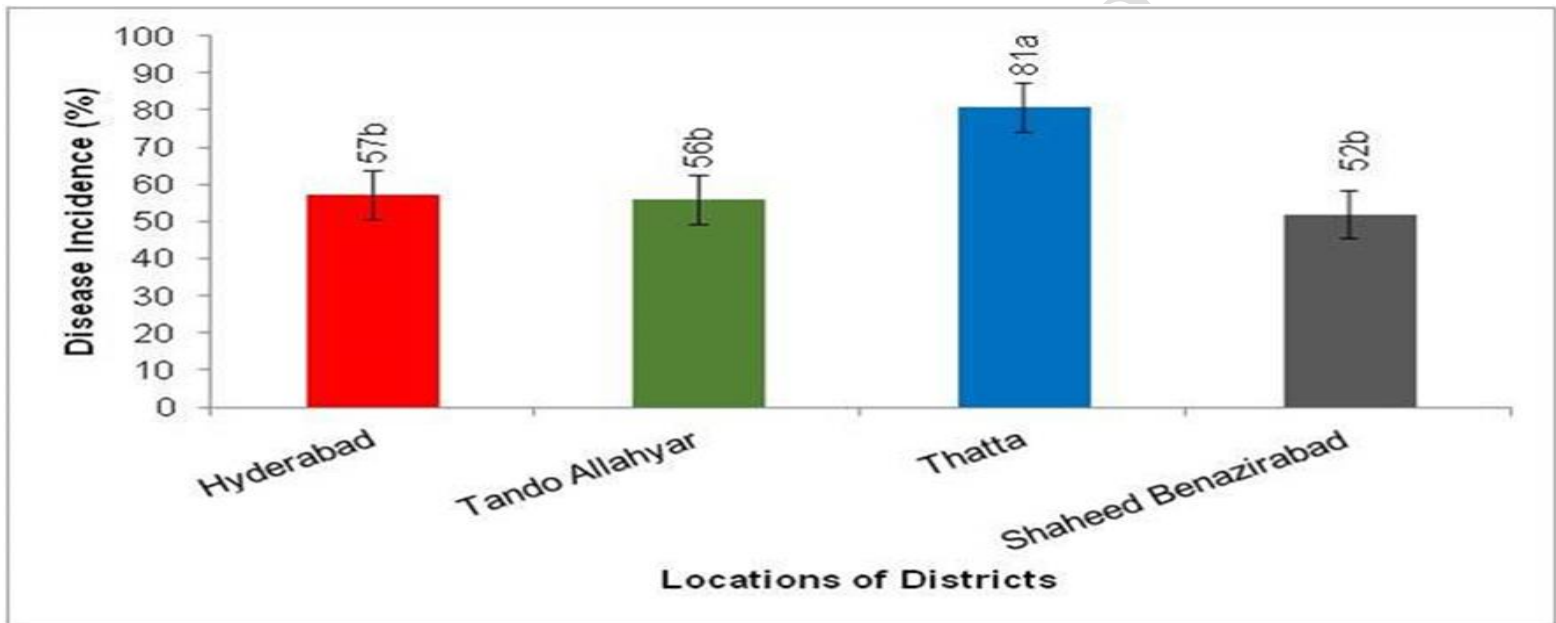

Figure 5. Average cucumber mosaic disease incidence (\%) at different surveyed districts of Sindh

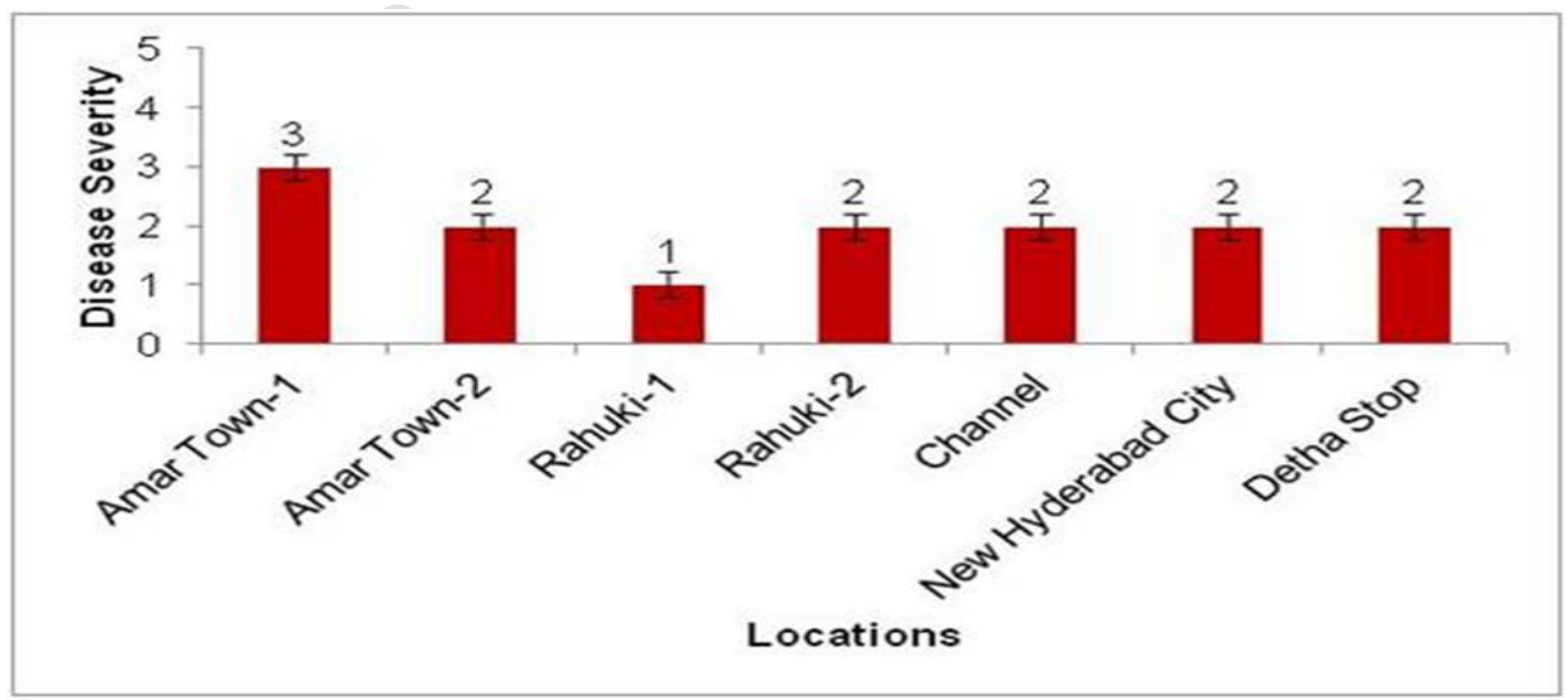

Figure 6. Cucumber mosaic disease severity at different locations of district Hyderabad 


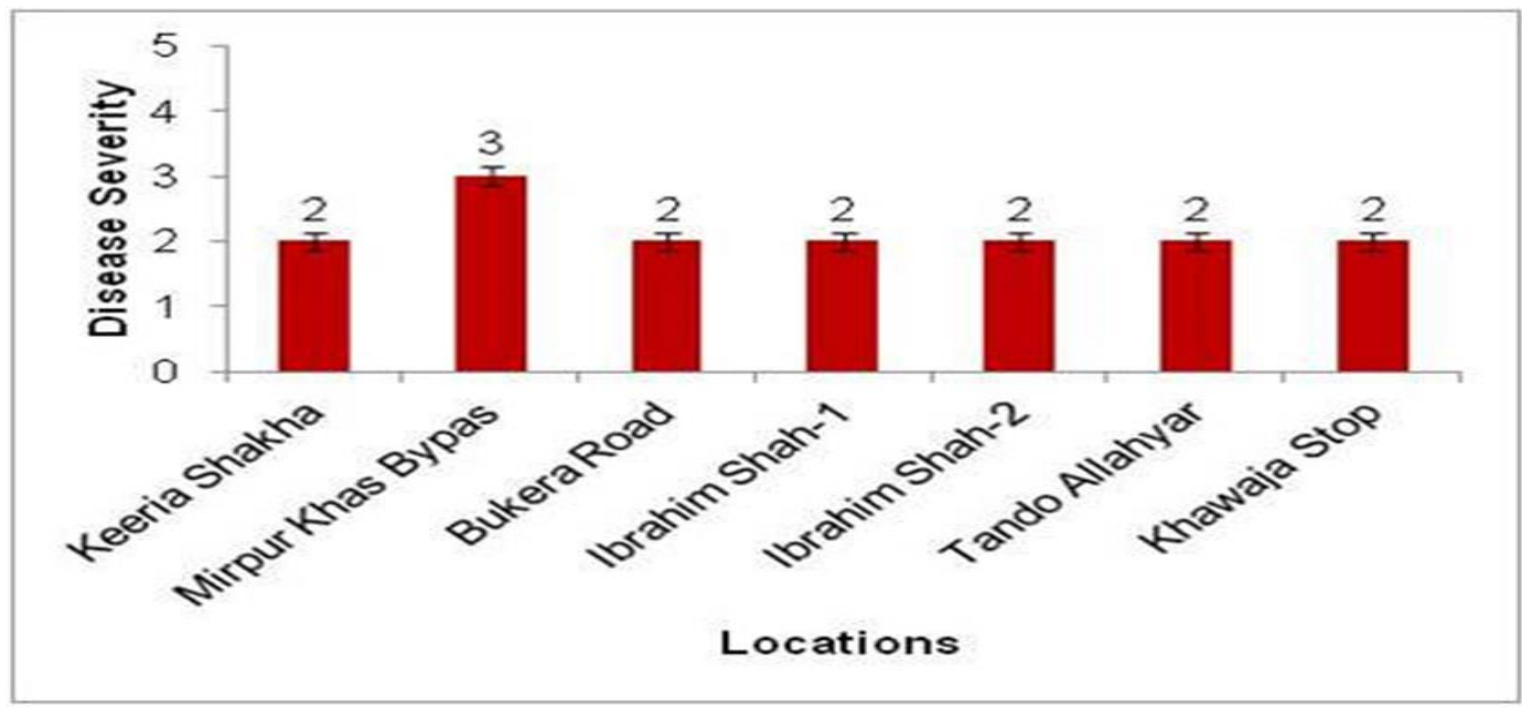

Figure 7. Cucumber mosaic disease severity at different locations of district Tando Allahyar

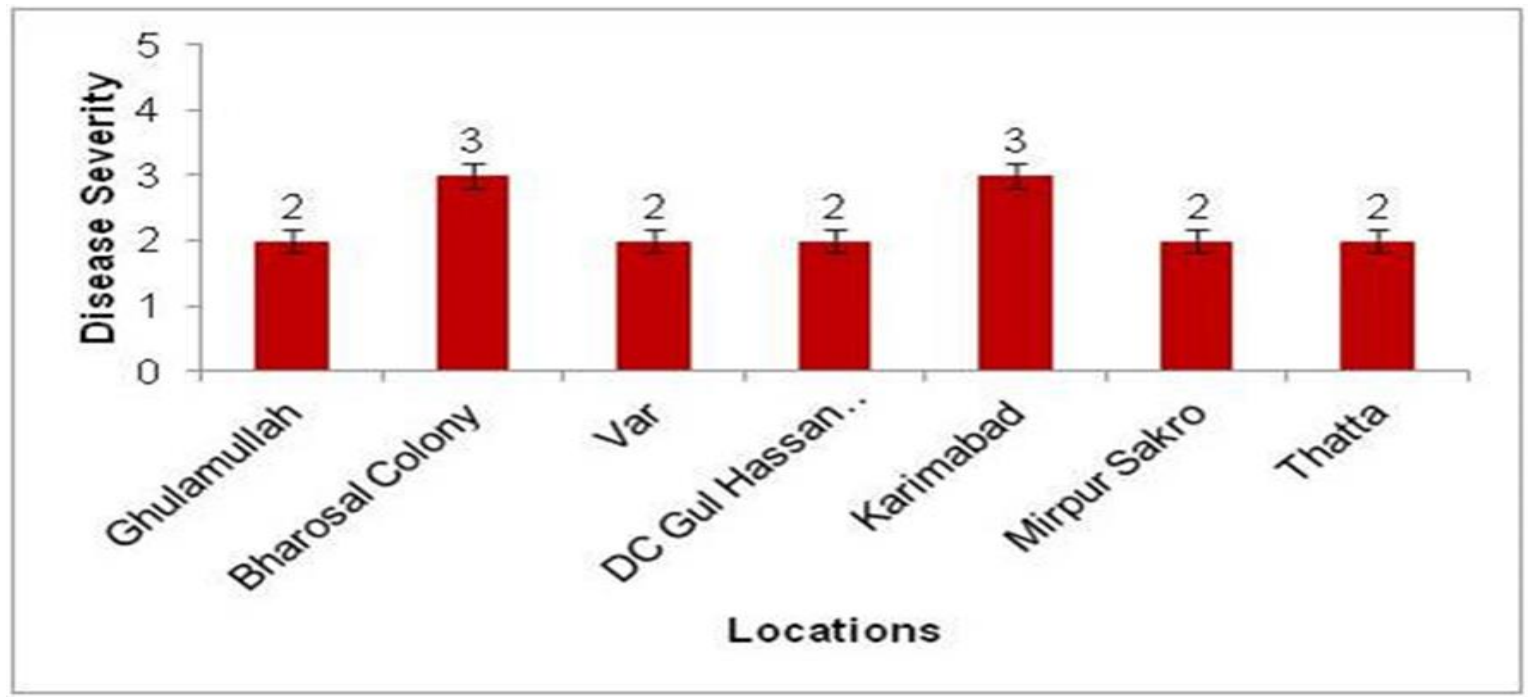

Figure 8. Cucumber mosaic disease severity at different locations of district Thatta

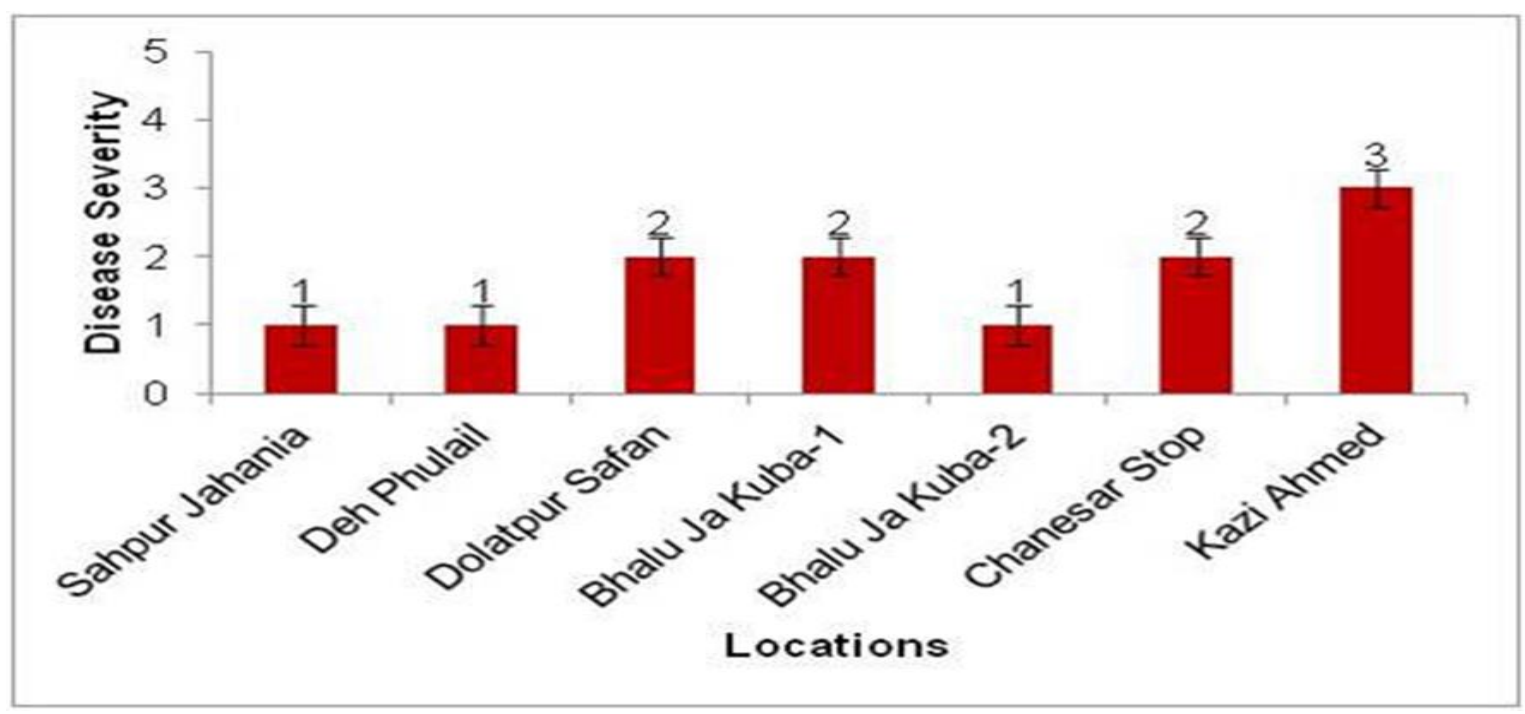

Figure 9. Cucumber mosaic disease severity at different locations of district Shaheed Benazirabad 


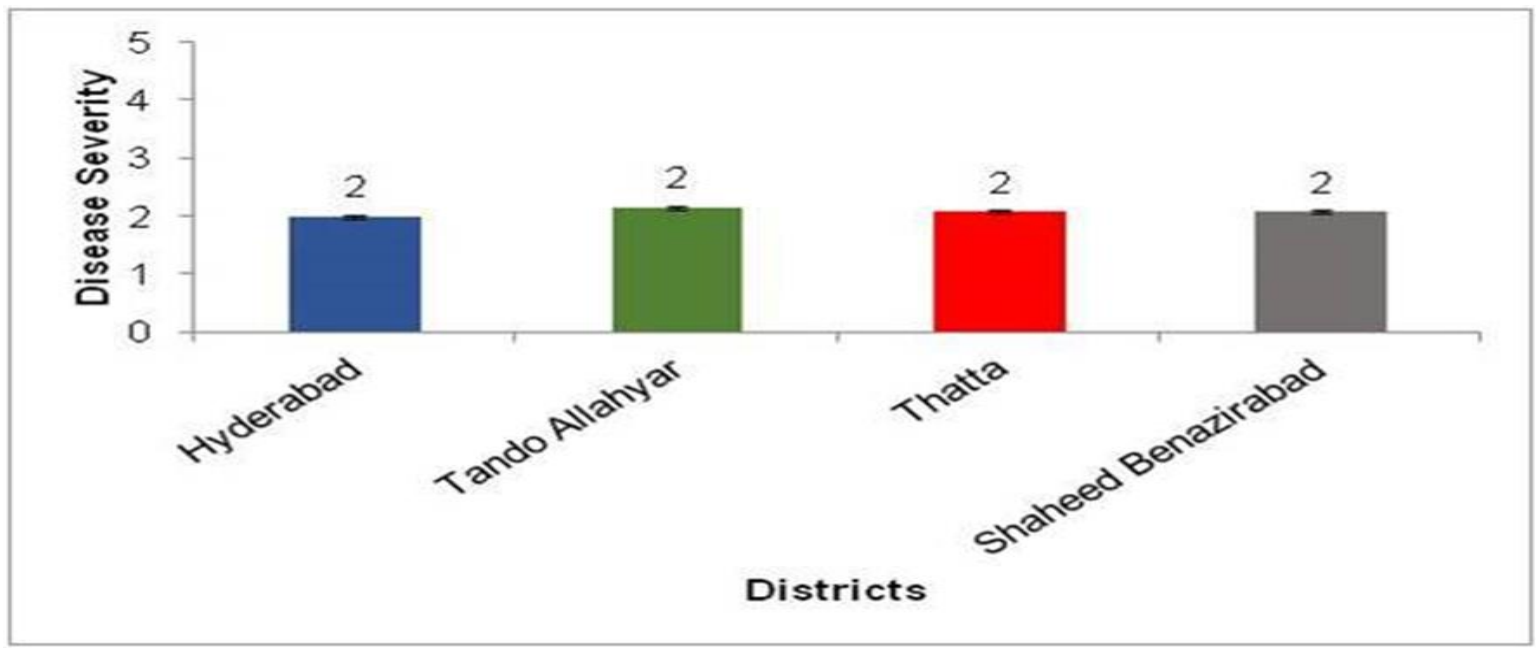

Figure 10. Average cucumber mosaic disease severity at different surveyed districts of Sindh

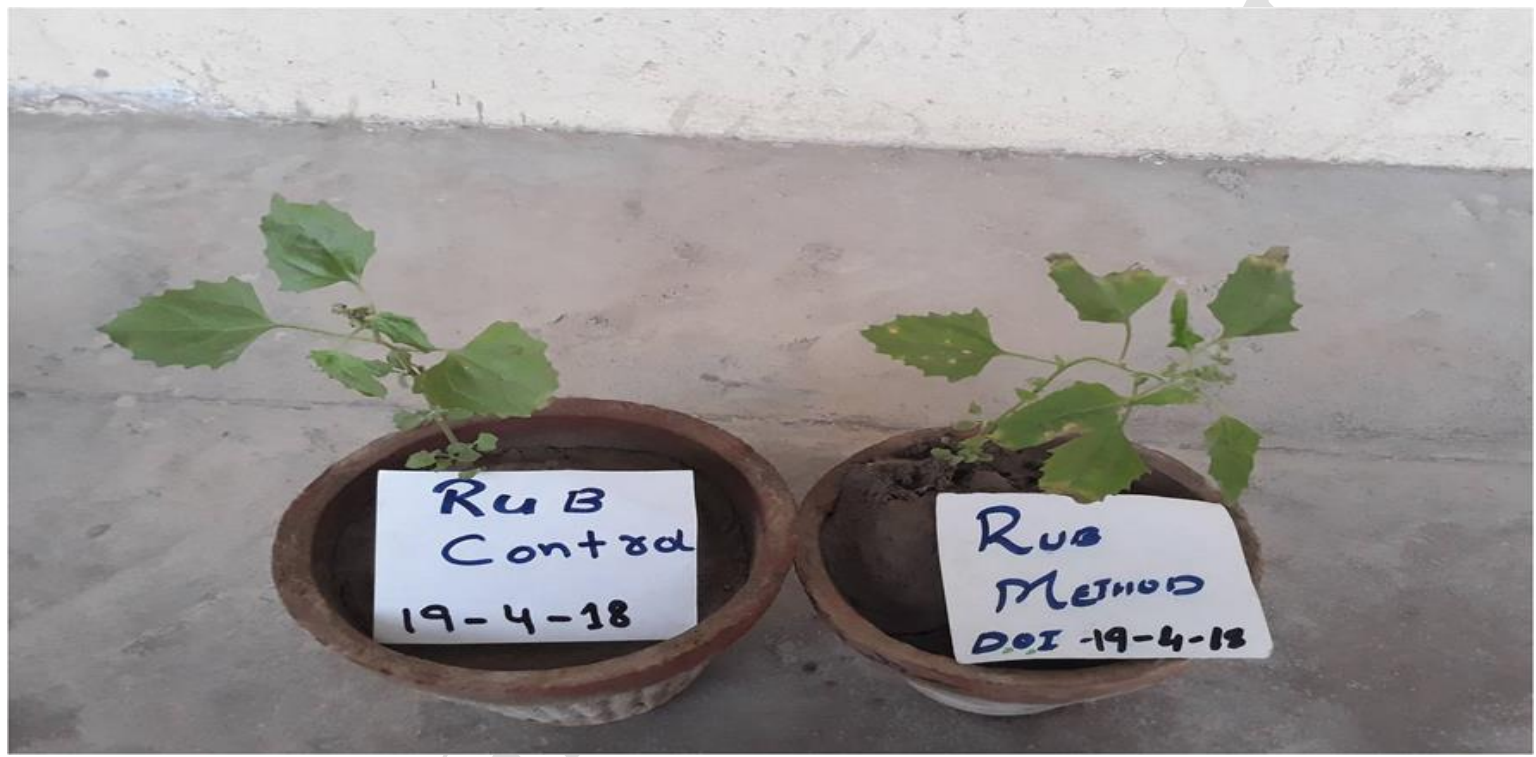

Figure 11. Chenopodium amarenticolor plants inoculated with sap of cucumber mosaic virus and un-inoculated as control

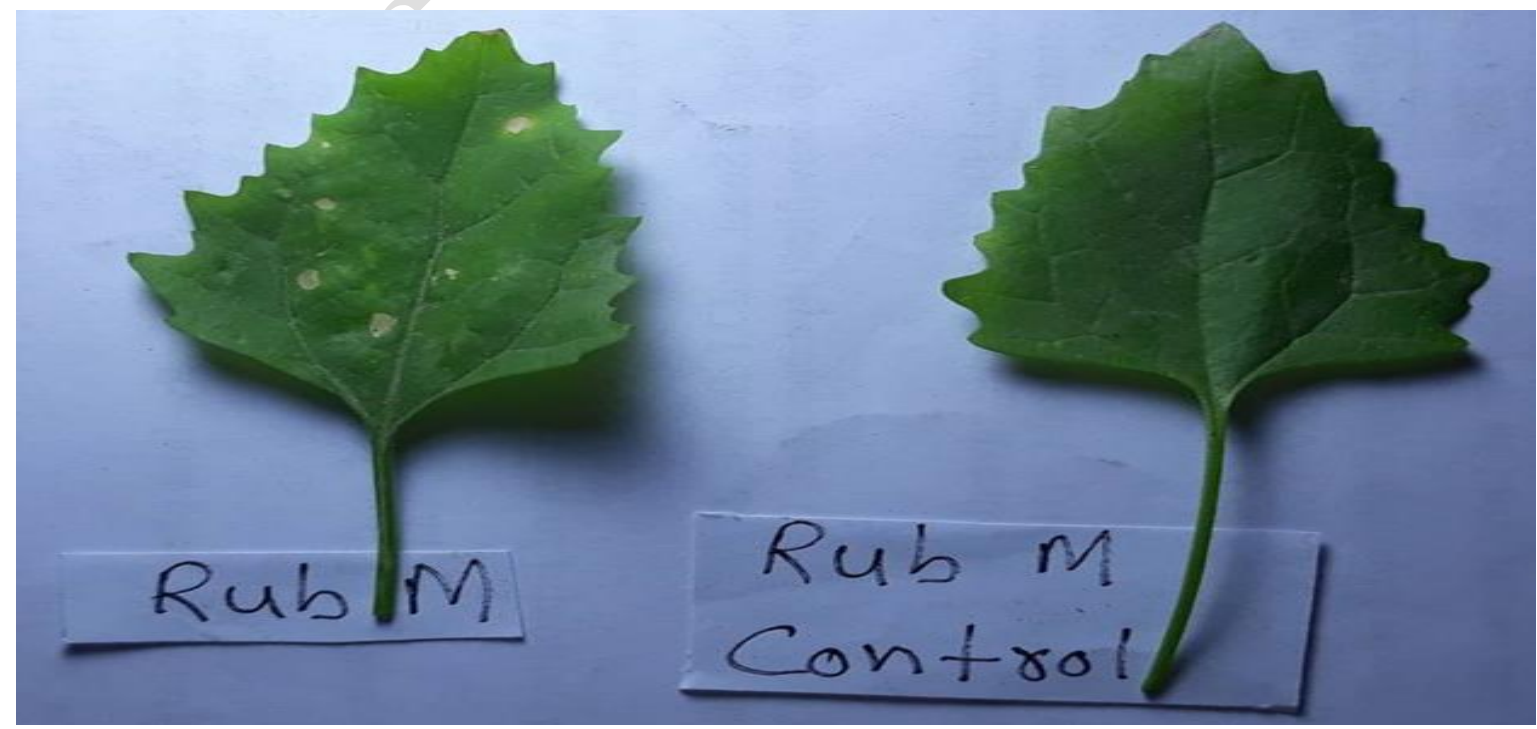

Figure 12. Necrotic lesions on leaves of inoculated Chenopodium amarenticolor plants 
Bhutto et al.

Table 1. Correlation of environmental conditions with the incidence and severity of cucumber mosaic disease

\begin{tabular}{|c|c|c|c|c|c|}
\hline $\begin{array}{c}\text { Disease } \\
\text { parameters }\end{array}$ & $\begin{array}{c}\text { Minimum } \\
\text { Temperature } \\
\left({ }^{\circ} \mathbf{C}\right)\end{array}$ & $\begin{array}{c}\text { Maximum } \\
\text { Temperature } \\
\left({ }^{\circ} \mathbf{C}\right)\end{array}$ & $\begin{array}{c}\text { Relative } \\
\text { Humidity } \\
(\%)\end{array}$ & Cloudiness & Evaporation \\
\hline $\begin{array}{c}\text { Disease } \\
\text { incidence }(\%)\end{array}$ & $r^{2}=0.664^{*}$ & $r^{2}=0.883^{* *}$ & $r^{2}=0.259$ & $r^{2}=0.600$ & $r^{2}=0.827^{*}$ \\
\cline { 2 - 6 } & $P=0.0482$ & $P=0.0053$ & $P=0.3030$ & $P=0.0705$ & $P=0.0119$ \\
\hline $\begin{array}{c}\text { Disease } \\
\text { severity }\end{array}$ & $r^{2}=0.462$ & $r^{2}=0.513$ & $r^{2}=0.148$ & $r^{2}=0.975^{* * *}$ & $r^{2}=0.599$ \\
\cline { 2 - 6 } & $P=0.137$ & $P=0.1089$ & $P=0.4522$ & $P=0.0002$ & $P=0.0708$ \\
\hline
\end{tabular}

\section{Conclusion}

Maximum disease incidence was recorded at Thatta followed by Shaheed Benazirabad, Tando Allahyar and Hyderabad with 2 severity score. Necrotic lesions on inoculated leaves of indicator plant Chenopodium amarenticolor were produced after 15 days of mechanical inoculation. Impact of environmental conditions like minimum and maximum temperature and evaporation showed significant correlation with the cucumber mosaic disease incidence. Cloudiness was highly significantly correlated with disease severity, whereas relative humidity was not related to the disease development.

\section{Authors' contributions}

Designed experiment, analyzed data and prepared manuscript: JUD Hajano, Conducted experiments and prepared manuscript: MS Bhutto \& AG Kandhro, Designed experiment: ZA Nizamani \& KH Dhiloo, Provided chemicals: L Kumar, Prepared manuscript: KH Wagan, Analyzed data and edited manuscript: AR Jarwar.

\section{Acknowledgements}

The authors acknowledge the administrative staff of the Department of Plant Pathology, Sindh Agriculture University, Tandojam 70060-Pakistan for providing laboratory facilities.

\section{References}

1. Khan ZA, Shah H, Gul R, Majid A, Khan U \& Ahmad H (2015). Morpho-agronomic characterization of cucumber germplasm for yield and yield associated traits. Int $J$ Agron Agric Res 6: 1-6.

2. Maurya GP, Pal V, Singh GP \& Meena LK (2015). An economic analysis of cucumber cultivation in Sultanpur District of Uttar Pradesh (India). Int J Agric Sci Res 5: 23-27.

3. FAOSTAT (2016). Food and Agriculture Organization of the United Nation. Database collection. http://ww w.fao.org/faostat/en/\#data/QC.

4. Akbar A, Ahmad Z, Begum F, Ubairah \& Raees N (2015). Varietal reaction of cucumber against Cucumber mosaic virus. Am J Plant Sci 6: 833-838.

5. Roossinck MJ, Zhang L \& Hellwald KH (1999). Rearrangements in the 5 non translated region and phylogenetic analyses of Cucumber mosaic virus RNA 3 indicate radial evolution of three subgroups. J Virol 73: 6752-6758.

6. Akhtar KP, Yussouf M, Saleem M, Asghar MA \& Nighat S (2010). Resistance of Solanum species to Cucumber mosaic virus subgroup IA and its vector Myzus persicae. Eur J Plant Pathol 128: 435-450.

7. Agrios GN (2005). Plant Pathology $5^{\text {th }}$ Ed. Academic Press, New York. p 992.

8. Francki RIB, Mossop DW \& Hatta T (1979). Cucumber mosaic virus. CMI/AAB Descriptions of Plant Viruses, No. 213. Commonwealth. Mycological. Institute. Association. Applied. Biology, Kew, Surrey, England. 6pp.

9. Ferreira MBC, DaSilva RC, Medina JH \& Izquierdo I (1992). Late post-training memory processing by the entorhinal cortex: Role of NMDA and GABA-A receptors. Pharmacol Biochem Behav 41: 727-731.

10. Hill SA (1984). Methods in Plant Virology.Vol. I. Backwell, London.

11. Akanda AM (1991). Studies on the virus mycoplasma diseases of crops in Bangladesh. Ph. D. Thesis. Kyushu Univ., Japan. 
12. Palukaitis P \& García-Arenal F (2003). Cucumoviruses. Adv Virus Res 62: 241323.

13. Perez JL, Espino-Gudiño MC, TorresPacheco I, Guevara-González RG, Herrera-Ruiz G \& Rodríguez-Hernández V (2011). Quantification of virus syndrome in chili peppers. Afr $J$ Biotechnol 10: 5236-5250.

14. Hajano J, Zhang HB, Ren YD,.Lu CT \& Wang XF (2016). Screening of rice (Oryza sativa) cultivars for resistance to rice black streaked dwarf virus using quantitative PCR and visual disease assessment. Plant Pathol 65: 1509-1517.

15. Cooke BM., Gareth D \& Kaye B (2006). The Epidemiology of Plant Diseases. $2^{\text {nd }}$ Edition. Springer.

16. Naidu RA \& Hughes Jd'A (2001). Methods for the detection of plant virus diseases, In: Plant virology in sub-Saharan Africa, Hughes Jd'A \& Odu BO, (Eds.), 233-260, Proceedings of a Conference Organized by IITA, International Institute of Tropical Agriculture, ISBN 9781312149, Nigeria.

17. Sastry KS (2015). Plant virus and viroid diseases in the tropics. Volume 1: Introduction of plant viruses and sub-viral agents, classification, assessment of loss, transmission, and diagnosis. Virus Dis 26: 324.

18. Iqbal S, Ashfaq M, Shah H, Ul-haq M I \& Uddin A (2012). Prevalence and distribution of cucumber mosaic virus in major chilli growing areas of Pakistan. Pak J Bot 44: 1749-1754.

19. Khan MA, Mahmood $Y$ \& Shafque $M$ (2011). Effectiveness of plant based insecticides as a sustainable means of control of cucumber mosaic virus. Afr $J$ Food Agric Nutr Dev 11: 5473-5492.

20. Hord MJ, García A, Villalobos H, Rivera C, Macaya G \& Roossinck MJ (2001). Field survey of Cucumber mosaic virus subgroups I and II in crop plants in Costa Rica. Plant Dis 85: 952-954.

21. Lobin KK, Svoboda J, Lebeda A, Dhooky DY \& Benimadhu SP (2015). Cucumber mosaic virus causal pathogen of oily spots on cucumber cv. locale fruits in Mauritius. Plant Protect Sci 51: 123-126.

22. Supyani S, Chandra A, Rochman F, Septariani DN \& Widadi S (2017). Occurrence and distribution of cucumber mosaic virus in cucurbits in Karanganyar, Central Java, Indonesia. Afr J Agric Res 12: 1593-1601.

23. Martin B, Collar JL, Tjallingii WF \& Fereres A (1997). Intracellular ingestion and salivation by aphids may cause the acquisition and inoculation of nonpersistently transmitted plant viruses. $J$ Gen Virol 78: 2701-2705.

24. Roossinck MJ (2001). Cucumber mosaic virus, a model for RNA virus evolution. Mol Plant Pathol 2: 59-63.

25. Ng, JC \& Perry KL (2004). Transmission of plant viruses by aphid vectors. Mol Plant Pathol 5: 505-511.

26. Rahman MS, Akhter, Alam MM, Pervin N \& Akanda AM (2016). Prevalence of cucumber mosaic virus and its impact on growth and yield of different chili cultivar. Bulletin of the Institute of Tropical Agriculture, Kyushu University. 39: 6574.

27. Imran M, Khan MA, Fiaz M, Azeem M \& Mustafa M (2013). Influence of environmental conditions on tomato mosaic virus disease development under natural condition. Pak J Phytopathol 25: 117-122.

28. Zeshan M A, Khan MA, Ali S, Arshad M \& Ahmed N (2016). Epidemiological studies of tomato leaf curl virus disease based upon environmental variables. Int J Agric Biol 18: 1061-1066.

29. Haider S, Khan MA \& Jahanzaib M (2017). Characterization of epidemiological factors for the whitefly (Bemisia tabaci Genn.) population and tomato leaf curl virus disease (TLCVD) incidence on tomato genotypes in Faisalabad, Pakistan. J Entomol Zool Stud 5: 747-752. 